\title{
Identificação de terminologias comuns em trabalhos científicos: O plágio e suas implicações
}

Em quase todo o mundo, principalmente em países europeus como a Ingleterra, a apropriação de idéias, palavras e imagens de uma pessoa, por outra inadvertidamente e sem os devidos créditos, é considerada uma prática muito repudiada, principalmente na educação superior. Até, uma pequena parte de seu manuscrito que contenha plágio, pode ter sérias consequências, seja em atribuição de notas insuficientes ou até a expulsão da instituição de ensino.

Os Estados Unidos é um outro exemplo, onde a prática do plágio é considerada como muito séria e, igualmente sujeita a sanções acadêmicas. Autores como John Edlund, da Califórnia State University, consideram que o plágio viola diretamente a honestidade intelectual e, como tal, é passível de investigações pelas agências de fomento à pesquisa em diversos países.

Em pesquisas científicas, tem sido aplicado todo o rigor necessário quando acontecem denúncias de plágio nas publicações acadêmicas. Trata-se de uma política de não tolerância a tais práticas, que vem sendo adotada através dos periódicos nacionais e internacionais. Exceto nas grandes revistas, ainda não aparecem informações mais detalhadas sobre as questões envolvendo o plágio e a ética relacionadas ao artigo científico. E, tão pouco são as punições tão severas, ficando mesmo os autores acusados de plagiar, com a punição de não mais poderem submeter seus trabalhos a este ou àquele periódico científico.

O conceito de plágio ainda não parece, para alguns pesquisadores, algo muito bem explicitado. Sua abordagem é envolta pelo conceito de uma autoria e de uma propriedade intelectual. Sendo assim, quando um autor publica uma determinada seqüência de palavras ou frases ao expressar suas ideias, esse, de fato, seria o dono de tais ideias. Dessa forma, a utilização de tais palavras, sem que se dê o devido crédito ao autor, se configuraria em roubo. Interessante quando lidamos com culturas diferentes tais como a cultura chinesa, onde uma ideia pertence à cultura, portanto cabe a sociedade compartilhá-la e difundi-la entre os indivíduos. Observe-se que aqui, não se configura roubo de ideias. 
É grande a atenção dada às questões envolvendo o plágio nas universidades e também em órgãos de financiamento de pesquisas. Embora que, países como a China, Singapura e Coréia não compartilham dessa mesma visão sobre a propriedade intelectual, isto é, a autoria e a originalidade não sejam tão valorizadas como no Ocidente.

A noção tradicional de propriedade intelectual, nestes países, é mais coletiva do que mesmo individual. Dessa forma, num contexto multicultural, há muitos conflitos e dilemas éticos possíveis, que decorrem da visão sobre a autoria e a produção textual. É preciso que se desenvolvam mecanismos e estratégias educacionais, capazes de minimizar tais diferenças, quanto à visão do texto do artigo científico.

No Brasil pouco se discute sobre plágio em ciências. Talvez, não pela ausência do problema no país, mas pela falta de iniciativas que busquem aprofundar discussões sobre essa temática.

Em resumo, a discussão sobre as dimensões da prática do plágio, principalmente na academia é de valorosa contribuição para a atividade científica. Diante da relevância deste tema seria ingênuo, não se buscar discutir de forma pragmática, o plágio nas universidades, bem como nas outras diversas instituições de pesquisa. Incluam-se aí, os programas de pósgraduação.

Uma maior orientação sobre tal prática, deveria estar presente nas políticas educacionais e nos diversos programas de pós-graduação. Ações conjuntas tendem a ser mais efetivas em seus propósitos.

Gislene Farias de Oliveira*

Editora

*Docente na faculdade de Medicina da Universidade Federal do Ceará. Doutora em Psicologia Social e Editora Gerente da Id on Line Revista Multidisciplinar e de Psicologia. Contato: gislenefarias@ gmail.com. 